\title{
FOUNDERS' VALUES CONTRIBUTING TO THE INTERGENERATIONAL SUCCESSION OF LARGE FAMILY BUSINESSES
}

\author{
Hadi Cahyadi NG ${ }^{1 *}$, Jacob Donald Tan $^{2}$, Sugiarto Sugiarto ${ }^{3}$, Anton Wachidin Widjaja ${ }^{4}$, \\ Rudy Pramono 5
}

${ }^{1}$ Faculty Member, Faculty of Economics and Business, Universitas Tarumanagara, Indonesia

Email: hadic@fe.untar.ac.id

${ }^{2}$ Faculty Member, Faculty of Economics and Business, Universitas Pelita Harapan, Indonesia

Email: jacob.tan@uph.edu

${ }^{3}$ Faculty Member, Faculty of Economics and Business, Universitas Prasetiya Mulya, Indonesia

Email: sugiarto.sugiarto@pmbs.ac.id

${ }^{4}$ Faculty Member, Faculty of Business, President University, Indonesia

Email: antonwachidinwidjaja@gmail.com

${ }^{5}$ Faculty Member, Center for Research and Community Development, Universitas Pelita Harapan, Indonesia

Email: rudy.pramono@uph.edu

*penulis korespondensi

Masuk : 22-12-2020, revisi: 25-12-2020, diterima untuk diterbitkan : 25-12-2020

\begin{abstract}
ABSTRAK
Studi ini menganalisis nilai-nilai pendiri yang berkontribusi pada suksesi antargenerasi dari bisnis keluarga besar yang dianggap konglomerat di Indonesia. Akses informan dalam usaha keluarga besar ini masih langka, terutama karena sifat usaha keluarga yang tertutup. Dengan demikian, meskipun beberapa peneliti telah membahas hubungan antara nilai dan umur panjang, studi yang menyinggung bisnis keluarga besar di ekonomi yang sedang berkembang ini masih minim. Selain itu, penting untuk mengetahui bagaimana nilai-nilai para pendiri mempengaruhi umur panjang bisnis keluarga besar mereka, mengingat dampak kelompok konglomerat tersebut terhadap perekonomian Indonesia. Para peneliti menggunakan Interpretative Phenomenological Analysis (IPA) dengan mewawancarai 15 informan yang terdiri dari penerus dan profesional non-keluarga kunci dari 5 kelompok konglomerat. Pengamatan dan catatan lapangan juga dicatat untuk melakukan triangulasi dengan data wawancara. Penelitian ini mendorong wawasan empiris baru ke dalam nilai-nilai para pendiri dalam mengubah manajemen bisnis keluarga dan umur panjang mereka. Temuan tersebut mengungkapkan bahwa nilai-nilai integritas dan kewirausahaan pendiri adalah yang teratas, diikuti oleh kesopanan, kepercayaan, tujuan yang lebih tinggi, dan kepercayaan kepada Tuhan. Nilainilai yang ditimbulkan ini menopang umur panjang bisnis keluarga besar hingga generasi berikutnya dan membuka jalan potensial untuk penelitian di masa depan.
\end{abstract}

Kata Kunci: bisnis keluarga besar, nilai pendiri, suksesi antargenerasi, fenomenologi, Indonesia.

\section{ABSTRACT}

This study analyzed the founders' values that contribute to the intergenerational succession of large family businesses that are considered conglomerates in Indonesia. The access to the informants in these large family businesses is scarce, especially due to the reserved nature of the family business. Thus, even though several researchers have addressed the relationship between values and longevity, the studies that allude to large family businesses in this emerging economy is still scant. Besides, it is vital to investigate how the values of the founders 
affect the longevity of their large family businesses, considering the impact that these conglomerate groups have on Indonesia's economy. The researchers employed the Interpretative Phenomenological Analysis (IPA) by interviewing 15 informants composing of successors and key non-family professionals from 5 conglomerate groups. Observations and field notes were also taken note of to triangulate with the interview data. This research induced new empirical insights into the founders' values in transforming their family business management and longevity. The findings revealed that the founder's values of integrity and entrepreneurship are among the top, followed by modesty, trustworthiness, a higher purpose, and trust in God. These elicited values underpin the longevity of large family businesses into the next generations and enkindle potential avenues for future research.

Keywords: large family businesses, founders' values, intergenerational succession, phenomenological, Indonesia.

\section{INTRODUCTION}

The founders' cultural values and family traditions to their successors depend mainly on the founders' cultural orientations, the environments in which they were brought up, and their longterm visions for the firms. Schein (1990) mentioned that organizations are developed through the founder's apt leadership who has a vision of creating a mark in the business world. From the humble beginning, mostly decades ago, the founders built their businesseses and then turned them into good organizations. Eventually, with their predecessors, the founders produced great results from Good to Great (Collins, 2001). The founders then keep their goals to ensure the firms' longevity (Collins et al., 2005). However, the road to longevity is not necessarily smooth. It is a fact that family businesses have been strived to improve their governance, leadership transition, and somewhat, even sustainability.

Family businesses play a critical role in East Asia, including Korea, Japan, Taiwan, China, Indonesia, and Thailand (Park et al., 2015). Samsung is a family-controlled conglomerate, similar to many other leading corporations in Korea. It contributes to more than $20 \%$ of the country's GDP, which is approximately equal to overall government spending. McKinsey, in the Quarterly Report, provides a bold projection that by $2025,40 \%$ of the emerging markets' largest enterprises (Revenue > US\$1 billion) will be family or founder-controlled businesses (Bjonberg et al., 2014). Hence, large family businesses (LFBs) play a prominent part in Korea's national economies. In Indonesia, as compiled by the researchers from Bloomberg Terminal, the average revenues of family businesses (FAM), state-owned-enterprise (SOE), and multi-national company (MNC) are approximately US $\$ 110$ billion, US $\$ 43.8$ billion, and US\$39.9 billion, respectively. The contribution of FAM or LFBs to the country's GDP is exhibited in Fig. 1 (data compilation from Bloomberg terminal by researchers between 2013 and 2017). 


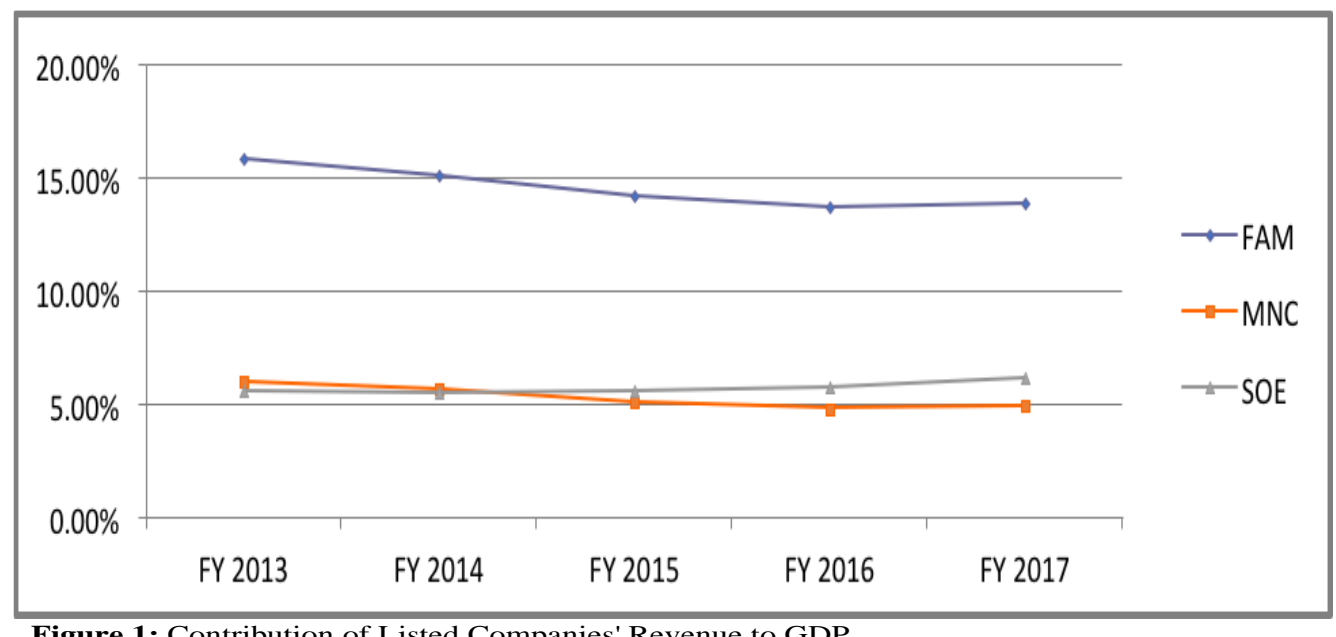

Figure 1: Contribution of Listed Companies' Revenue to GDP

Source: Data Compilation from Bloomberg Terminal by Researchers in 2018

The failure of intergeneration succession, among the blame and the succession topic, has been the most prominent research subject in the literature of family business (Benavides-Velasco et al., 2013; Debicki et al., 2009; and Sharma et al., 2003) and the defining feature of the field (Yu et al., 2012). It is not surprising that the research conducted by John Ward of Northwestern University's Kellogg School, in line with those facts, which concluded $30 \%$ of family businesses could survive to the second generation. However, only $13 \%$ of them could pass it to the third generation (Beckhard \& Dyer Jr., 1983; and Ward, 2016), and later Family Business Institute added that and $3 \%$ operate into the fourth or beyond.

On the other hand, we have also heard numerous family-enterprise success stories whereby those family, the harmony, health, and longevity cases seem to be exceptions to the rule. Moreover, the impact of founders' influence is paramount to those success stories. The founder is a central figure who plays a significant factor in giving impacts on family businesses' behavior (Davis \& Harveston, 1999; Kelly et al., 2000). The survival of the large family business into the business dynasty's longevity is the notion of this research.

This current research is good because it introduces new scientific studies to this limited field of research, the issue of founder's value and the contribution to family business management, and it is applicable in a multi-national context. This study also in line with study to understand the link between longevity and values and the importance of values for longevity, to continue the study of Tàpies and Moya (2012) to investigate the significance of values in many different family firms type, which keeps up with the study by Sharma et al. (2003). Furthermore, these research findings are beneficial to the LFBs, educators, researchers, family businesses and family business owners/managers themselves. They may gain insight into the founder's influence through the founders' values. For this reason, this research was designed to understand the potential impacts of the influence of the founders, especially in different generational stages and many other different businesses.

\section{LITERATURE REVIEW}

Definition of Values. Aronoff and Ward (2000) illustrated that values are the core of what humans do to succeed and commit. Values encourage people to do something difficult, make 
disciplinary decisions, and adhere to long-term plans (Mintz, 2018). Another characterization of values comes from Dumas and Blodgett (1999), who stated that values answer what is meaningful. Dumas and Blodgett (1999) described core values as deep-rooted principles that impact most areas of people's lives, namely the people's moral convictions, attitude to other people, dedication to objectives of both individual and organizational (Aronoff \& Ward, 2000). The other two suitable and unique conceptions of values came from several researchers. Kluckhohn (1951) rendered a notion of value as an overt or implied conception of what is desirable, which determines the variety of possible forms, the means, and the ends of action (Dumas \& Blodgett, 1999; Kluckhohn, 1951).

This study focuses on the founders' influence on family business management to discover their values contributing to longevity. The influence is also a major aspect in signifying on the behavior of family businesses (Davis \& Harveston, 1999; Kelly et al., 2000). A founder's presence may have a huge impact on the family business, both when the founder still gets involved as owner/manager and when they retire or passes away. This condition may leave the company's management to other same-generation and/or subsequent generation family-member and/or non-family-member managers. Early research into the influence of founders resulted in mixed results, with some scholars suggesting that founders have trajectories of consequences that are hard to depart (Boeker, 1988). In contrast, other studies concluded that founders have a little lasting impact on their companies, as organizations are mixable and adaptive, and they respond to environmental shifts (Teece et al., 1997).

In recent times, the founder's influence on family firms has been given different researchers' labels. Davis \& Harveston (1999) specifically studied the founder's influence on subsequent managers, and they call this influence "generational shadow." In a multigeneration family firm, the founder could cast a generational "shadow" on the company and its vital processes. In such a case, "succession" is not deemed complete, can limit successors, and can influence the company's efficiency in a chaotic manner. However, this "shadow" may also positively impact by providing a clear set of values, the directions, and also the standards for subsequent firm managers. Davis \& Harveston (1999) concluded especially that the founder's generational shadow's strength had both positive and significant correlation with organizational conflict in the third-generation family firms. A similar scientifically valid correlation has not yet been found among second-generation companies. However, the authors found an increasing number of conflicts in the second-generation family business when the founder was still involved in its management.

Kelly et al. (2000) focused primarily on the founder's influence on current managers, similarly proposed that a family firm founder's "legacy centrality" will give influence to family-member managers' strategic behavior, with both positive and negative impacts. We can observe three dimensions of "legacy centrality" and "betweenness centrality" (involving the founder's power), "closeness centrality" (a distance measure between the founder and other firm managers), and "connectivity centrality" (which measures the relationship between the founder and various managers). They postulated that the founder's centrality would impact a family business's strategic management, particularly strategic vision, strategic goals, culture, strategy behavior, and inward/outward orientation. In addition, family businesses with a strong centrality history may be susceptible to major economic or competitive changes. 
Value of Familiness. A rather different but key idea for understanding the family business is the value of familiness. Habbershon \& Williams (1999) first introduced the concept of familiness had contributed in several things, one of which is the social capital approach to familiness. The goal is to understand the essence of family businesses further. Habbershon and Williams (1999) and Habbershon et al. (2003) assumed that familiness is the idiosyncratic, firm-level bundle of resources and capabilities which resulted from a family factor (Habbershon, 2006). Chrisman et al. (2003) put it differently by defining familiness through the influence of the vision established by the dominant coalition of family stakeholders through political processes of value determination. In contrast, Habbershon and his collaborators stressed the result of familiness focuses on its creation (Chrisman et al., 2003).

Pearson et al. (2008) categorized the family-firm resources into a structural, cognitive, and relational dimension, whose interactions result in family-firm capabilities. Pearson et al. (2008) saw familiness as a resource derived from family relationships. Thus, when we comprehend familiness, we consider it a resource for family firms made up of more than one generation of family members working within the business (Irava \& Moores, 2010).

Longevity. In terms of longevity, the Japanese family business model has been adopted by family business owners who plan to transfer their values and practices from one generation to the next. However, only a few Japanese and global context companies are successful (Chirapanda, 2019). Japan is regarded as a nation with long-term businesses. Prof. Toshio Goto of the Japan University of Economics has reported almost 3,937 companies in operation for more than 200 years. They are predominantly family-owned enterprises, accounting for about 45 percent of all long-lived businesses worldwide (Goto, 2013). Aligned with the context mentioned above, some scholars in the family business have pointed out that these core business values are familyowned company's hallmark (i.e. Aronoff \& Ward, 2000; Corbetta \& Montemerlo, 1999; Tàpies $\&$ Ward, 2008; Ward, 1997; Ward, 2016). These values are so distinctive that they continuously provide a competitive advantage which is not duplicable to other firms as these values are not easy to imitate.

\section{METHODOLOGY}

Subsequently, through purposive sampling, the researchers approached 5 LFB conglomerate groups and interviewed 15 respondents consisting of successors in the second and third generation, and non-family members professionals. For method triangulation, the researchers also applied observations and field notes. The researchers engaged in Interpretative Phenomenological Analysis (IPA) to explore how the informants experience their founders' values during intergenerational succession. It is assumed that people are actively selfinterpreting to the events, objects, and people in their lives (Taylor \& Charles, 1985). Table 1 shows the successors and key non-family members' profiles. The interviews were conducted in 2020 .

Table 1. Profiles of Informants

\begin{tabular}{llllcll}
\hline No & Respondents & Generation & Gender and Role & Family & Type of Industry & $\begin{array}{c}\text { Year } \\
\text { of } \\
\text { Establi } \\
- \\
\text { shment }\end{array}$ \\
\hline 1. & \#1AJRG3M & Successor, $3^{\text {rd }}$ Gen, Age 35 & Male/ CEO & A & LFB - Diversified & 1950 \\
\hline
\end{tabular}




\begin{tabular}{|c|c|c|c|c|c|c|}
\hline 2. & \#2CNCSG3M & Successor, $3^{\text {rd }}$ Gen, Age 32 & Male/ Director & $\mathrm{C}$ & $\begin{array}{l}\text { LFB Property } \\
\text { Diversified }\end{array}$ & 1981 \\
\hline 3. & \#3EHAG3M & Successor, Gen 3, Age 50 & Male/ Chairman & $\mathrm{E}$ & $\begin{array}{l}\text { LFB }- \text { FMCG } \\
\text { Diversified }\end{array}$ & 1958 \\
\hline 4. & \#5ASRAG2M & Successor, Gen 2, Age 60 & Male/ Chairman & A & LFB - Diversified & 1950 \\
\hline 5. & 8CSTBODM & $\begin{array}{l}\text { Non Family Professionals, } \\
\text { BOD, Age } 54\end{array}$ & Male/ Director & $\mathrm{C}$ & $\begin{array}{l}\text { LFB Property } \\
\text { Diversified }\end{array}$ & 1981 \\
\hline 6. & \#9BLOG2M & Successor, Gen 2, Age 54 & Male/ CEO & $\mathrm{B}$ & $\begin{array}{l}\text { LFB }- \text { Media } \\
\text { Diversified }\end{array}$ & 1965 \\
\hline 7. & $\begin{array}{l}\# 13 \mathrm{CNSBOC} \\
\mathrm{F}\end{array}$ & $\begin{array}{l}\text { Non-family Professionals, } \\
\text { BOD, Age } 57\end{array}$ & Female/ Director & $\mathrm{C}$ & $\begin{array}{l}\text { LFB Property } \\
\text { Diversified }\end{array}$ & 1981 \\
\hline 8. & $\begin{array}{l}\# 10 \mathrm{CBSOG} 2 \\
\mathrm{MD}\end{array}$ & Successor, Gen 2, Age 62 & $\begin{array}{l}\text { Male, Managing } \\
\text { Director }\end{array}$ & $\mathrm{C}$ & $\begin{array}{l}\text { LFB Property } \\
\text { Diversified }\end{array}$ & 1981 \\
\hline 9. & $\begin{array}{l}\# 14 \mathrm{CHHG} 2 \mathrm{M} \\
\mathrm{D}\end{array}$ & Successor, Gen 2, Age 60 & $\begin{array}{l}\text { Male/ Managing } \\
\text { Director }\end{array}$ & $\mathrm{C}$ & $\begin{array}{l}\text { LFB Property } \\
\text { Diversified }\end{array}$ & 1981 \\
\hline 10. & $\begin{array}{l}\text { \#16BGOG3F } \\
\text { BOC }\end{array}$ & Successor, Gen 3, Age 32 & Female/ BOC & $\mathrm{B}$ & $\begin{array}{l}\text { LFB }- \text { Media } \\
\text { Diversified }\end{array}$ & 1965 \\
\hline 11. & $\begin{array}{l}\text { \#17AAWG2M } \\
\text { D }\end{array}$ & Successor, Gen 3, Age 27 & Male/ Director & A & LFB - Diversified & 1950 \\
\hline 12. & $\begin{array}{l}\text { \#20DJAG2BO } \\
\mathrm{C}\end{array}$ & Successor, Gen 2, Age 53 & Male/ Chairman & $\mathrm{D}$ & $\begin{array}{l}\text { LFB - Pharma } \\
\text { Diversified }\end{array}$ & 1966 \\
\hline 13. & \#22DVVBOD & $\begin{array}{l}\text { Non-family Professionals, } \\
\text { BOD, Age } 54\end{array}$ & Male/CEO & $\mathrm{D}$ & $\begin{array}{l}\text { LFB - Pharma } \\
\text { Diversified }\end{array}$ & 1966 \\
\hline 14. & $\begin{array}{l}\text { \#24ACRG3B } \\
\text { OD }\end{array}$ & Successor, Gen 3, Age 35 & $\begin{array}{l}\text { Female/Managing } \\
\text { Director }\end{array}$ & A & LFB - Diversified & 1950 \\
\hline 15. & $\begin{array}{l}\# 27 \text { ABRG3FB } \\
\text { OD }\end{array}$ & Successor, Gen 3, Age 29 & Male/ Director & A & LFB - Diversified & 1950 \\
\hline
\end{tabular}

\section{FINDINGS AND DISCUSSIONS}

According to Tàpies and Ward (2008), values transmits from one generation to another in the families involving business through living together, taking place in the process of socialization, through education, with the interrelation of the family members, in meetings. In addition, the next-generation family members learn about values by living them and watching and listening to the older generation. Furthermore, the most suitable instrument for the writing of values, the family code or the family constitutional or the family covenant is written, acknowledged and ratified by all members of the family.

Altruism. A family is a group of people bound in social values, in which altruism requires the parents to minister to their children, encourages the members of the family to guard one another, and values family membership by continuously strengthening the family tie and well-being across generations. The emphasis on altruism and compassion is related to terminology that suggests the normative orientation of one's self towards others. Therefore, the terminologies will interchangeably be in use. The family-owned firms are expected to have a mindset of concern for other people based on family influence. Family $\mathrm{C}$, for instance, described of founder's value of altruism, how the founder concern with the fulfilment need of every stakeholder; the Family $\mathrm{E}$ also put togetherness and interdependent each other as a critical corporate principle:

\section{Question $(Q)$ : What are statements Founders often mention repeatedly to you?}

"He believes in big scale projects and long-term returns. He shows business must do with "begin with the end in mind." [...] We are also concerned about other stakeholders' interests; we want everybody to fulfill their needs. We sacrifice and grow together with our tenant, supplier, 
employee, and other stakeholders. We play long term games" - Mr. \#2CNCSG3M, 3rd Gen., Family C, Male 32, Director.

"Success is born through honesty, persistence, and commitment in the light of constant prayer. We also praise togetherness. Any exit strategy, all employees mentioned how togetherness is one of value here. We call it as Interdependent Co-Arising"--Mr. \#3EHAG3M, 3rd Gen., Family E, Male 50, Commissioner.

"Yes, as a Christian, we believe in God's design and God's plan. However, as Chinese, we believe in Tao (Tao is the natural order of the universe whose character one's human intuition must discern to realize the potential for individual wisdom). And, he often mentions that we must start the business with a noble mission in a business to grow with other people. We can be successful if we begin at the in mind to grow people, in order for us to be successful in business. Otherwise, we will go against nature" - Mrs. \#24ACRG3BOD, $3^{\text {rd }}$ Gen., Family A, Female 35, Managing Director.

"For my dad, this business is really a blessing entrusted to our family; hence, we need to give it back to society and represent people underrepresented. We are encouraged to do business in order to ignite job creation [---]. For him, the inspiring moment, and he loves so much, if he meets a retired employee, especially the low-level, came to face him, bring his son/ daughter. Especially whenever the son/ daughter has graduated from college, for example, to become a medical doctor. He is so proud and happy, indeed [---], and he portrays our business as the same as the tree. If we got the fruits, we do not sell off the fruits, but we replant the seeds. So the seeds will grow another tree. If we have money, we reinvest back for job creation, beyond profit" - Mr. \#9BLOG2M, Family B, $2^{\text {nd }}$ Gen., Male 54, CEO.

Current research concludes the relationship between generosity and longevity values (Musick et al., 1999). It means that people in community service may possibly live longer than others who do not engage in any form of helping behavior. In this context, a sense of well-being and satisfaction is correlated with hospitality implications for families in the industry. Generosity turns out to have a huge impact on the communities and helps the family members see that the purpose and a reason to work together in the business project truly make sense. Generosity is such a meaningful and powerful meaning for families in business, beyond solely economic profit (Ceja et al., 2010).

The generosity to close members of the family and larger stakeholders are related to empathy. According to Rushton et al. (1989), generosity means as follow: i) an experience of another individual's affective state, ii) an emotion of tender loving care following after someone's empathy. Batson (1990) defined generosity toward others as an individual's empathetic emotional experience toward the person who is in need. Therefore for business families, showing their descendants to be empathic toward people may be a way to cultivate and transmit the importance of generosity. An excellent method of increasing empathy among the family members is by engaging them in many philanthropic activities. The senior generation plays a vital role because the family members learn the most pro-social behavior during their childhood and teenage from them. The older generations have the golden opportunity to embody the younger generations with generosity. The closed corporation could be a superb path for engaging the next generations with philanthropic activities. Family members can take parts and appreciate the pride of belonging to a family business which shared the sense of humanity. Others deserve consideration for their own sake, not for economic or utilitarian purposes. 
Chirapanda (2019) tried to identify success factors contributing the Japanese family businesses sustainability. The research finding showed that the success factor is involving the local community by building their connections among the locals. Most Japanese family businesses acknowledged the significance of community in their business, especially in times of crisis. In consequence, the Japanese think of building good relations by hiring the people from the local community and rising long-term CSR programs to benefit the local community. According to Goto (2014), social cohesion and personal investment in the community is indispensable, and they consider the personal relationships' networks as important things to promote trust, collaborative work, and communal activities.

In addition to Family $\mathrm{C}$ and Family E, our study found that Family A shows the importance of working for others' benefit, must be a mission of their attention to growing with other people. They believe that they can only be successful if we begin at the in mind to grow people, in order for them to be successful in business. Otherwise, they will go against nature. Moreover, Family $\mathrm{B}$ realizes that the business is a blessing entrusted to their family. Most of the interviewers mentioned that profits are not merely the main focus, but there is the so-called "beyond profit." Hence, they believe in giving back to the society, especially underrepresented people, and focusing on job creations.

Humility. It appears to be an essential value for family businesses. The "Collins English Dictionary" (2003) stated that a "humble" person is "conscious of one's failings, unpretentious." Peterson \& Seligman (2004) defined "humility" as "letting one's accomplishments represent themselves; not seeking the spotlight; not regarding oneself as more special than one is." This value is often considered behavioral, which later can be classified as a virtue.

Early in the time of starting the family businesses, many founders promoted determination, responsibility, dedication, and hard work. Then, there came the virtue of humility as time went on as standard origins for many of the family businesses. Peterson \& Seligman (2004) concluded humility as an essential gateway for the family business to signify the humble heritage for their survival and continuity in business. For example, the founders of Family A and B stated that values are required to be reincarnated by future generation:

"Our grandfather tells us that we need to have a fighting spirit or the ability to endure in a crisis. We seldom talk about our ambition, and on the other hand, we often discuss our vision. Grandpa often tells the story of how he has gone through the World War and financial crisis in 98. We do not even was born yet. Besides, he also mentions that we need to have a sense of urgency or sense of crisis, so we have the stamina to survive of the crisis." Mr. \#17AAWG2BOD, $3^{\text {rd }}$ Gen., Family A, 27, Male, Director.

"My grandfather has never thought he will become a businessman. He got the calling to be a priest, and then become a teacher. But God has a different plan for him. With our Company in media now, it is like a vehicle for us [---] I feel like God will, God purposely choose my grandfather to know for a specific purpose in this life. If others build this Company, I do not think the Company will be grown like this. Perhaps, it will grow with different values, indeed. However, my grandfather, as a founder, who put his value of humility and humanist a platform, 
Company become a media company that signifies underrepresented people" - Mrs. \#16BGOG3BOC, $3^{\text {rd }}$ Gen., Family B, 32, Female, Commissioner.

"My father is a simple person. Very very modest. Another founder also a very simple person, Perhaps $m$ father was born as a teacher's son, from a very ordinary family. He never wants to be a businessman; he feels blessed and feels that God has a different plan. His business planning is also so simple, not profit-oriented. He only thinks how the business achieves a higher purpose such as job creation and represents the underrepresented people" - Mr. \#9BLOG2M, Family B, 2nd Gen., Male 54, CEO.

"When we are in a meeting or on holiday, my dad enjoys the conversation. And, he likes to try something new and unique. He does not like the conversation of buying luxury kinds of stuff like a private jet or big yacht. He likes conversation that to stimulate our interest in the business". Mr. \#5ASRAG2M, Family A, 2nd Gen., 60, Male, Chairman.

On individual well-being and organizational efficiency, the founder's humility's importance passes on to the next generation. Studying how families in the industry can cultivate humility deserve our paying attention. Although the simplest methods for fostering humility have few empirical results, some psychological approaches benefit family-owned businesses. The principle of appreciation, for instance, may possibly be beneficial for fostering humility within business families. In response to receiving a gift, Seligman \& Royzman (2003) describes "gratitude" as a feeling of gratitude and pleasure, whether the gift is tangible from another individual or serves as a good memory after a particular circumstance. In a family business in the form of patrimony and rank, each generation receives a tangible gift. Therefore, it is essential to cultivate an appreciation for the previous generations who have preserved and strengthened the closed company to market a humble spirit within each generation. By realizing that what they now have is merely the grace of God and needs to be used for a greater cause, the founder of Family B passes this humility on to the next generation.

One major effect on an individual's well-being lies down in the practice of writing a journal of gratitude (Emmons \& Crumpler, 2000). Journaling help people reflect on their time and feel thankful for everything they need. Gratitude is a good mindset that can help people foster modesty over generations (Ceja et al., 2010). Stressing that every closed corporation is exclusive makes positive significance. Consequently, "standard" interventions will not occur for cultivating the worth of humility. The practice of humility and gratitude would lead families in business to be grateful and stay humble before their family predecessors and their roles within the closed corporation (Ceja et al., 2010; Emmons \& Crumpler, 2000).

Entrepreneurship. It is another valuable characteristic of family-owned firms. Stevenson (1983) described entrepreneurship as the pursuit of opportunity regardless of currently controlled resources (Stevenson, 1983). Similarly, Baron (2010) described "entrepreneurship" as an active venture to initiate new businesses. The entrepreneurship's value is concluded to be connected to fostering value development through individual initiative; therefore, we are talking about a behavioral value (Baron, 2010; Stevenson, 1983). Consequently, it can be categorized as an attitude.

The entrepreneurship is profoundly embedded in the culture of family-owned businesses. It roots deeply, especially within the founder's initiation to start a business and a work culture over the 
generations among the family members. Family can serve as a socializing agent to build a sense of achievement on an individual. The founder thought of enterpreneurship as a considering variable in a person's entrepreneurial behavior (Amabile, 1988; McClelland, 1978; Mumford, 2000). The entrepreneurship would be a powerful instrument to drive a family member to start a business, especially when the atmosphere of business is deep-rooted in the family. When the family members build a sense of entrepreneurship, they will dedicate their resources to ensure the innovation takes place in striving the business across generations.

"Since I was grown up, my dad always asking me whether I found any opportunity. Then, he loved to discuss it. He will follow it up; if I did not pursue it, he would ask why I do not pursue it? He advised me that I better take a risk than never. He suggested that I take a risk to pursue the opportunity, especially when we are still young. You cannot fail if you do not try it. You need to try it to experience making a mistake." - Mr. \#5ASRAG2M Family A, $2^{\text {nd }}$ Gen., 60, Male, Chairman.

"Entrepreneurship appreciates new ideas, from anybody. The founder is willing to listen and encourage anybody to give his or her opinion. It can find the new ventures, or the ideas how to do a more efficient way to conduct the business." - Mr. \#14CHHG2, Family C, $2^{\text {nd }}$ Gen., 60, Male, Managing Director.

“...So, umm, from a very young age, My grandfather always tells me that I always need to try, and to me, that means you have to have the spirit of the entrepreneur, and you always have to be willing to take risks even if there is a risk failure. If you do not try, you have definitely failed already. However, if you try it, the possibility of success is fifty-fifty. Maybe 30 percent you fail 70 percent of success. See there is always a risk of failure. My founder always says: if you have to be willing to try the job, you have the spirit of the entrepreneur". Mr. \#27ABRG3FBOD, Family A, $3^{\text {rd }}$ Gen., 29 Male, Director.

Family $\mathrm{C}$ accentuates encouraging the entrepreneurial spirit among employees to motivate them to pursue challenging and ambitious goals. Family A's founder encourages his children and grandchildren to try a new idea and dare to fail. Entrepreneurship's values are widely claimed to benefit any organization's success and survivability (Amabile, 1988; Mumford, 2000). Founders need to recognize that the longevity and growth of businesses rely on their penetrating new markets and revitalizing existing products and services.

Integrity. Several researchers included integrity and respect as core business values (Cavanagh \& Gerald, 1990; García-Marzá, 2005; Purba \& Tan, 2018). The researchers as well promoted truth, reputation, honesty, and responsibility as the core values other than integrity and respect. Nowadays, integrity and respect serve as the foundational values in many organizations. Both integrity and respect even become the top values and are considered as behavioral values. They can also be referred to as virtues.

"Imagine how our founder showing integrity by showing his work to us. He is partnering with three different groups, first with the government, with his friends, and then with all new business allies. We work with partners to grow the venture and profit from the venture, not from manipulating our partners. He shows us by giving an example, not merely his statement. He teaches us by giving an example. That is the basic of, we call it, Integrity [---] without integrity 
we cant work with so many different types of partners and so many business partners" -Mr. \#10CBSOG2MD, Family C, $2^{\text {nd }}$ Gen., 62, Male, Managing Director.

"We need integrity. Integrity means faith in God. With integrity, which we are always being honest and having strong moral principles and with God leads us the way, we even more agile" Mr. \#5ASROG2C, Family A, 2nd Gen., 60, Male, Chairman.

"[...] integrity is our main value than incarnated from the founder. And it is our main value. Because of Integrity, we are able to survive to overcome 98 's financial crisis. Without integrity, we cannot ally with so many business partners. I believe all of our business partners would do a background check before they are partnering with us. If we are not proven to implement the integrity value, they will not enter the partnership." Mrs. \#13CNSOBOD, Non-family Professionals, Family C, 57 Female, Director.

As presented above, Family A and Family C's Integrity as fundamental principles and behavior principles are transferred to the next generations. The business they own and the values diffused (Denison et al., 2004; Hall et al., 2001). Nicholson and Björnberg (2008) note that there is a need to sustain this commitment over decades, as both the business and the family extend. They found this is the way they live by implementing and incarnated the founder's value.

The article by Koiranen (2002) does not discuss the problem of transmission of the value. However, the Italian and French Henokiens associates' testimonies reach the same conclusion as the Spanish sample and illustrate the role of family history and customs in the transfer of values across generations (Koiranen, 2002; Tàpies \& Ward, 2008). The interviews did not address certain inquiries about value transmission, but our respondents mostly answered by indicating that values are transmitted by role-modeling, observing and imitating those values in practical settings.

The significance of founders' values on longevity. The impact of the founders' values on longevity, we collect respondents' opinions about how the listed values had essentially contributed to the firms' longevity. The findings of the interview with the Spanish group showed that respect, entrepreneurship and stewardship were the most highly rated values (Tàpies \& Ward, 2008). These are followed by "Loyalty" and "Honesty", then "Excellence", "Hard Work" and "Prudence", with "Quality" and "Profitability". The last in the lists were "Humility", "Reputation" and "Social Responsibility", with the lowest position on "Accountability". Then, we inquired the respondents which values have contributed the most to the sustainability of the company. The response varied depending on the particular family business. In contrast, Table 3 shows how the LFBs differ from its counterparts. The interview reveals that Integrity and Entrepreneurship are among the top mentions, followed by "Modesty", "Trustworthiness/ Honesty", "Beyond Profit/Higher Purpose" and "Trust in God's willing".

Table 2. The most values contributing to longevity

\begin{tabular}{ccccc}
\hline Family A & Family B & Family C & Family D & Family E \\
\hline Entrepreneurship & Beyond Profit & Integrity & Humanity & Honesty \\
Integrity & Modesty & Professionalism & Integrity & Persistence \\
Modesty & Integrity & Entrepreneurship & Trustworthiness & Commitment \\
\hline
\end{tabular}




\begin{tabular}{|c|c|c|c|c|}
\hline Higher Purpose & God's willing & - & Achievement & Prayer \\
\hline
\end{tabular}

The contribution of values to longevity. The respondents' interview results confirmed that the values ("Integrity", "Entrepreneurship", "Humility", and "Modesty") significantly affect the company to maintain longevity. The reason for their company's longevity turned out to be the values which became the core issue. We can emphasize one of the testimonies:

\section{Q: Could you describe why your Company can perpetuate to longevity?}

"The so-called values of Integrity, Professional, and Entrepreneurship are the values that make this family business survive. This is not only jargon but also a living principle that is implemented day by day. It is cool. The values are timeless from now and then. Professionalism is the value that makes us successful today. Entrepreneurship will make us successful tomorrow, and integrity is the forever core value. The founder feels this value is the reason to be perpetuated into longevity." - Mr. \#23CATMGTBOD, Family C, 60 Male, Senior Director.

\section{CONCLUSION AND IMPLICATIONS}

The Covid-19 pandemic disrupted our interview progress, so several interviews had to be through virtual conference and thus lacked observational process. Nevertheless, the in-depth interview sessions acquired enriching and saturated data to illuminate the founders' values. Interviewing the founders could also be implemented for future research to elevate the validity of the investigated data. Next, a cross-cultural study can be conducted to compare and contrast these founded values with similar studies conducted in different countries. Another central issue could also involve the evolution of founders' values.

Our findings reveal that a family is a group of people bound in social values. The values could elevate the family dynamics and foster care for matters outside of themselves (Erikson, 1993; Tàpies \& Ward, 2008).- Therefore, their distinct values such as humility, integrity, entrepreneurship that are elucidated in this study are essential for LFBs to foster stakeholder loyalty and dedication. There is a parent-child relationship in the household, characterized by altruism, which differentiates family businesses from other kinds of businesses. Altruism is a controlling force within family life extended to within the family firm, and from an economic point of view, altruism is to share utilities and welfare with other people (Schulze et al. 2003). The value of altruism that in this study is the value of doing business "beyond profit", meaning to do business but for a higher purpose such as job creation, representing the under-represented, grow together with other stakeholders.

These values will provide the family with a strong sense of reason and purpose to remain together in any of business projects. Overall, the distinctive traditions of family businesses seem to be influential in influencing the healthier communities found in family businesses, providing them with a strategic edge over non-family businesses. 


\section{Acknowledgement}

The authors would like to massively thank the Faculty of Economics and Business of Universitas Tarumanagara and Universitas Pelita Harapan for their supports, as well as the informants who are willing to participate in the interview sessions.

\section{REFERENCES}

Amabile, T. M. (1988). A model of creativity and innovation in organizations. Research in Organizational Behavior, 10(1), 123-167.

Anderson, R. C., \& Reeb, D. M. (2003). Founding-family ownership and firm performance: evidence from the S\&P 500. The Journal of Finance, 58(3), 1301-1328.

Aronoff, C. E., \& Ward, J. L. (2000). Family Business Values: How to Assure a Legacy of Continuity and Success, Family Business Leadership Series. Marietta, GA: Business Owner Resources.

Baron, R. A. (2010). Job design and entrepreneurship: Why closer connections= mutual gains. Journal of Organizational Behavior, 31(2/3), 370-378.

Beckhard, R., \& Dyer Jr., W. G. (1983). Managing continuity in the family-owned business. Organizational Dynamics, 12(1), 5-12.

Benavides-Velasco, C. A., Quintana-García, C., \& Guzmán-Parra, V. F. (2013). Trends in family business research. Small Business Economics, 40(1), 41-57.

Bjonberg, A., Elstrodt, H.-P., \& Pandit, V. (2014, December 1). The family-business factor in emerging market,. McKinsey Quarterly.

Cavanagh, G. F., \& Gerald, F. (1990). American business values. Prentice Hall Englewood Cliffs, New York.

Ceja, L., Agulles, R., \& Tàpies, J. (2010). The importance of values in family-owned firms.

Chirapanda, S. (2019). Identification of success factors for sustainability in family businesses. Journal of Family Business Management.

Chrisman, J. J., Chua, J. H., \& Litz, R. (2003). A unified systems perspective of family firm performance: An extension and integration. Journal of Business Venturing, 18(4), 467472.

Collins, J. (2001). Good to Great: Why Some Companies Make the Leap and Others Don't. Random House Business Books, London.

Collins, J. C., Collins, J., \& Porras, J. I. (2005). Built to last: Successful habits of visionary companies. Random House.

Corbetta, G., \& Montemerlo, D. (1999). Ownership, governance, and management issues in small and medium-size family businesses: A comparison of Italy and the United States. Family Business Review, 12(4), 361-374.

Davis, J. A., Hampton, M. M., \& Lansberg, I. (1997). Generation to generation: Life cycles of the family business. Harvard Business Press.

Davis, P. S., \& Harveston, P. D. (1999). In the founder's shadow: Conflict in the family firm. Family Business Review, 12(4), 311-323. 
Debicki, B. J., Matherne III, C. F., Kellermanns, F. W., \& Chrisman, J. J. (2009). Family business research in the new millennium: An overview of the who, the where, the what, and the why. Family Business Review, 22(2), 151-166.

Denison, D., Lief, C., \& Ward, J. L. (2004). Culture in family-owned enterprises: Recognizing and leveraging unique strengths. Family Business Review, 17(1), 61-70.

Dumas, C., \& Blodgett, M. (1999). Articulating values to inform decision making: Lessons from family firms around the world. International Journal of Value-Based Management, 12(3), 209-221.

Dyer Jr., W. G. (2003). The family: The missing variable in organizational research. Entrepreneurship Theory and Practice, 27(4), 401-416.

Emmons, R. A., \& Crumpler, C. A. (2000). Gratitude as a human strength: Appraising the evidence. Journal of Social and Clinical Psychology, 19(1), 56-69.

Erikson, E. H. (1993). Childhood and society. WW Norton \& Company.

García-Marzá, D. (2005). Trust and dialogue: theoretical approaches to ethics auditing. Journal of Business Ethics, 57(3), 209-219.

Goto, T. (2013). Secrets of family business longevity in Japan from the social capital perspective. In Handbook of Research on Family Business, Second Edition. Edward Elgar Publishing.

Goto, T. (2014): Family Business and Its Longevity. Kundai Review, Vol. 2., p. 78-96.

Habbershon, T. G. (2006). Commentary: A framework for managing the familiness and agency advantages in family firms. Entrepreneurship Theory and Practice, 30(6), 879-886.

Habbershon, T. G., \& Williams, M. L. (1999). A resource-based framework for assessing the strategic advantages of family firms. Family Business Review, 12(1), 1-25.

Habbershon, T. G., Williams, M., \& MacMillan, I. C. (2003). A unified systems perspective of family firm performance. Journal of Business Venturing, 18(4), 451-465.

Hall, A., Melin, L., \& Nordqvist, M. (2001). Entrepreneurship as radical change in the family business: Exploring the role of cultural patterns. Family Business Review, 14(3), 193208.

Irava, W. J., \& Moores, K. (2010). Clarifying the strategic advantage of familiness: Unbundling its dimensions and highlighting its paradoxes. Journal of Family Business Strategy, 1(3), 131-144.

Kelly, L. M., Athanassiou, N., \& Crittenden, W. F. (2000). Founder centrality and strategic behavior in the family-owned firm. Entrepreneurship Theory and Practice, 25(2), 2742.

Koiranen, M. (2002). Over 100 years of age but still entrepreneurially active in business: Exploring the values and family characteristics of old Finnish family firms. Family Business Review, 15(3), 175-187.

McClelland, D. C. (1978). Managing motivation to expand human freedom. American Psychologist, 33(3), 201.

Mintz, S. (2018, August 1). What are Values? Www.ethicssage.com.

Mumford, M. D. (2000). Managing creative people: Strategies and tactics for innovation. Human Resource Management Review, 10(3), 313-351. 
Musick, M. A., Herzog, A. R., \& House, J. S. (1999). Volunteering and mortality among older adults: Findings from a national sample. The Journals of Gerontology Series B: Psychological Sciences and Social Sciences, 54(3), S173-S180.

Nicholson, N., \& Björnberg, А. (2008). The Shape of Things to Come-Emotional Ownership and the Next Generation in the Family Firm. In Family Values and Value Creation (pp. 29-52). Springer.

Park, S. H., Li, S., \& Lien, Y.-C. (2015). Who's In Charge of Asia's Family Businesses. Forbes. www.forbes.com

Pearson, A. W., Carr, J. C., \& Shaw, J. C. (2008). Toward a theory of familiness: A social capital perspective. Entrepreneurship Theory and Practice, 32(6), 949-969.

Peterson, C., \& Seligman, M. E. P. (2004). Character strengths and virtues: A handbook and classification (Vol. 1). Oxford University Press.

Purba, J. T., \& Tan, J. D. (2018). Owners' integrity, customers' relations, and focused attitude as strategies for family business sustainability and growth: an empirical study. Journal of Economics, Business, and Accountancy Ventura, 21(2), 219-228.

Schein, E. (1990), “Organizational culture”, American Psychologist, Vol. 45 No. 2, pp. 109-19.

Schulze, W. S., Lubatkin, M. H., \& Dino, R. N. (2003). Toward a theory of agency and altruism in family firms. Journal of Business Venturing, 18(4), 473-490.

Seligman, M. E. P., \& Royzman, E. (2003). Happiness: The three traditional theories. Authentic Happiness Newsletter, July.

Sharma, P., Chrisman, J. J., \& Chua, J. H. (2003). Succession planning as planned behavior: Some empirical results. Family Business Review, 16(1), 1-15.

Stevenson, H. H. (1983). A perspective on entrepreneurship (Vol. 13). Harvard Business School Cambridge, MA.

Tàpies, J., \& Moya, M. F. (2012). Values and longevity in family business: evidence from a cross-cultural analysis. Journal of Family Business Management.

Tàpies, J., \& Ward, J. (2008). Family values and value creation: The fostering of enduring values within family-owned businesses. Springer.

Taylor, C. and C. T. (1985). Taylor, C., \& Charles, T. (1985). Philosophical papers: Volume 2, philosophy and the human sciences - Google Search. Philosophical Papers: Volume2, Philosophy and the Human Science.

Teece, D. J., Pisano, G., \& Shuen, A. (1997). Dynamic capabilities and strategic management. Strategic Management Journal, 18(7), 509-533.

Ward, J. (2016). Keeping the family business healthy: How to plan for continuing growth, profitability, and family leadership. Springer.

Ward, J. L. (1997). Growing the family business: Special challenges and best practices. Family Business Review, 10(4), 323-337.

Yu, A., Lumpkin, G. T., Sorenson, R. L., \& Brigham, K. H. (2012). The landscape of family business outcomes: A summary and numerical taxonomy of dependent variables. Family Business Review, 25(1), 33-57. 